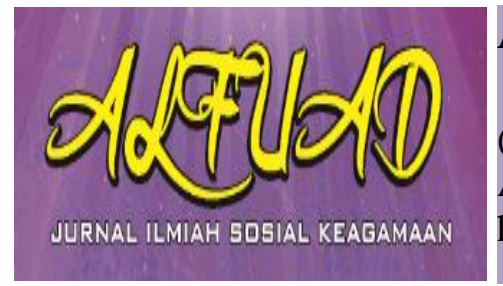

ALFUAD JOURNAL, 3 (2), 2019, (35-46)

(Print ISSN 2614-4786)

Available Online at

http://ecampus.iainbatusangkar.ac.id/ojs/index.php/alfuad

\title{
DIALECTIC MOTIVATION, BEHAVIOR AND SPIRITUAL PEAK EXPERIENCE IN THE PERSPECTIVE OF ISLAMIC PSYCHOLOGY
}

\section{Athoillah Islamy}

Institut Agama Islam Negeri Pekalongan, Indonesia

Email: athoillahislamy@yahoo.co.id

\begin{abstract}
This study aims to find the correlation of motivation, behavior and spiritual peak experience in the view of Islamic psychology. This type of research, namely qualitative research in the form of literature study. The primary data source of this research, namely the theory of hierarchy of human basic needs from Abraham Maslow. Meanwhile, secondary research data sources, namely various other relevant western motivational theories. The theory is used as a knife of analysis, namely the theory of motivation of the human soul from alGhazali which includes dimensions of heart, reason and lust. This study concludes that in the perspective of Islamic psychology there is a strong relationship between motivation and the behavior of every human being in the process of achieving spiritual peak experiences. The relationship of motivation and human behavior in the perspective of Islamic psychology that is more likely to emphasize religious motives (spiritual), both in psychological and physiological conditions of humans. motivation and behavior in Islam are very closely related to various stages in the process towards the ultimate spiritual human experience.
\end{abstract}

Keyword : Motivation, Behavior, Spiritual, Islamic Psychology

\section{INTRODUCTION}

Humans are creatures that can think and feel. Therefore, the behavior that he exhibits can be said to be a reflection of what he thinks and feels. On this basis psychology tries to examine further the symptoms that appear from what is thought and felt by humans.

Psychological studies of empirical symptoms that occur in humans have parameters that are not free of cultural bias. That is why successful psychology studies in the west are sometimes lacking or even not applicable to different social conditions. This shows the diversity of backgrounds that all have their respective characteristics. Based on these cultural diversity and paradigm factors, Islam as a religious teaching also has its own perspective on the study of Islamic psychology which has a distinction with the perspective of western psychology as in the study of the relationship between motivation, human behavior and the peak 
of spiritual experience (Nurlita, 2015:56). Therefore, in this paper we will explain how human motivation and its relationship with behavior and processes leading to spiritual peak conditions experienced in the perspective of Islamic psychology.

\section{METHOD}

This type of research is library research. The primary source used in this study is The theory of hierarchy of human basic needs from Abraham Maslow. Meanwhile, secondary research data sources, namely various other relevant western motivational theories. The theory is used as a knife of analysis, namely the theory of motivation of the human soul from al-Ghazali which includes dimensions of heart, reason and lust.

\section{RESULT AND DISCUSSION}

\section{Discourse on Human Motivation and Behavior}

Motivation is a mental condition or mental attitude that gives energy to humans to take action in order to achieve a goal. Motivation can also be said as a driving force that moves the ability, expertise, energy and time in order to achieve goals (Maryani, 2016 : 4). Therefore, motivation can be understood as an important element that is a driving force for humans to act, behave or try to realize the goals that have been determined.

There are at least three motivational theories that can help us understand the important elements in motivation, including the following. First, content theory. This theory emphasizes the importance of understanding the various factors in humans that cause them to behave. This theory tries to answer questions like, what needs will make someone feel satisfied? What causes them to do something? In this case, every individual has a need in him (inner needs) that drives him to do something in order to make it happen. Second, theory process. This theory emphasizes more on how or in what way each individual can be motivated to behave. In this view, necessity is only one element in a process of how humans behave. Third, reinforcement theory. This theory explains how the consequences of past behavior can influence future actions in a process cycle. Thus, humans can behave in certain ways because in the past they learned that certain behaviors can cause or cause positive and pleasant things or vice versa (Maryani, 2016: 5).

From the explanation of the three motivational theories above, it can be understood that each theory has a different 
element of emphasis - different motivating someone to act.

As for the relationship between motivation and behavior, Cook as quoted by Maryani explained that motivation is a strong decision that can encourage someone to do greater activities than do other activities. This explanation contains three elements. (1) Some needs, motives, or goals that drive an activity. (2) The selection process that directs the choice of activities. (3) The level of business intensity. From these three elements, it can be concluded that basically motivation has various elements that strengthen one another in connecting a motivation with one's behavior.

One theory of motivation in humanistic psychology that alludes to the relationship of motivation and human behavior can be seen in the theory of the level of basic human needs (hierarchy of human's basic needs) proposed by Abraham Maslow. In this theory, Maslow explained that human needs are not equal, they are logically classified and arranged in five levels of needs that motivate humans to behave (Abraham H. Maslow, $1987: 15-22)$. The five levels of need are as follows. (1) Physiological Needs (physiological need), (2) Safety Needs, (3) Belongingness and Love need, (4) Esteem needs, (5) Self Actualization Needs (self actualization need).

According to Maslow, if needs at the most basic (physiological) level have been met, then humans will tend to put more emphasis on meeting the next level of needs (security, belonging and love, respect) to the highest level of need (selfactualization). Maslow arranged the five levels of human needs in the form of a pyramid. Starting with physiological needs as the base of the pyramid which gets the largest portion of all the needs on it. After that the need for security, love, selfconfidence and then increasingly smaller portions. Maslow's theory is a controversial theory among researchers, especially in the characteristics of meeting the five needs based on hierarchical order (Akbar, 2012 : 2). From this it can be concluded that the hierarchy of basic human needs according to Abraham Maslow shows that humans have a tiered motive (need) as a stimulus to carry out certain actions, behaviors (actions) in realizing certain goals.

In subsequent developments, various other contemporary motivational theories were born. Clayton Alderfer through his empirical research rearranged Maslow's five needs into three needs categories known as ERG theory. This 
ERG theory explains that there are three categories of needs, namely the need for existence, relationships and growth. According to this theory, various needs can be managed in certain conditions without being determined by the level, that is not as the application of Maslow's hierarchy of needs theory. In addition to Clayton Alderfer, David Mc Clelland also sparked three needs as the main motivation for humans to act or behave. The three needs are achievement, power and affiliation. The need for achievement is the drive to strive to achieve the desired success. Meanwhile, the need for power is the need to make others act as they want or control of certain objects. While the need for affiliation is the need for close and close relationships between individuals and communities (Maryani, $2016: 7-8)$.

From the explanation of the various motivational theories above it can be concluded that there is a causal relationship between motivation in humans and their behavior in realizing certain goals.

\section{Motivation and Human Behavior Psycho-Sufi Perspective}

In the perspective of Islamic psychology, Islam is a religious teaching that contains a source of values that can be used as guidelines for living in shaping psychological conditions and good human behavior. Therefore, a person who understands the teachings of Islam correctly and runs all the rules of the religion, will be reflected through the glory of his daily behavior (Yuriadi, 2016: 225-226). From this it can be understood that Islamic psychology makes spiritual foundation as a value and motivation in character formation.

Motivation in the process of forming behavior (personality traits) of humans can at least be found from the substance of human existence itself which consists of physical, spiritual and nafsani substances. These three substances can be clearly distinguished although they cannot be separated. Physical substance is one aspect of human beings that is material (biological). Form and existence can be sensed by humans, such as the body and its members such as hands, feet, eyes, ears and others that are included in the structure of physical organisms. While the substance of the Spirit is the substance of human psychology which is the essence of life. Some experts refer to the spirit as the subtle body (jism latif). There are also those who call it a simple substance (Jauhar basith) and there is also a spiritual substance (jawhar ruhani). $\mathrm{He}$ is the 
driving force for the existence of unseen (abstract) human bodies. Meanwhile, the nafsani substance is a human psychophysical substance. In this substance, actualization of the nafs forms a behavior whose development is influenced by internal and external factors. The Nafsiyah aspect has an inherent potential that exists in human psychophysics which is carried from birth and which will be the driving force and determinant of human behavior.

As for the aspect of nafsiyah there are at least three dimensions that can provide motivation for someone to act or behave (Gumiandri, 2011: 280-290). The three dimensions are as follows.

\section{Dimensions of the Heart (Al-Qolb)}

Al-Ghazali divided the notion of the heart into two; the heart that is physical and the heart that is spiritual. Physical heart is one of the organs contained in the human body in the form of a lump of flesh shaped like a fruit of sanubar (sanubari) or like a banana heart located in the left chest. This heart is usually called the heart. While the soul's soul is something that is subtle (Lathif), rabbani and spiritual that are related to the physical heart. This part is human essence. This heart is the essence of human beings, because its nature and condition can accept, be willing, think, recognize, and do good deeds and be subject to God's commands, punishment, blemishes and demands. This spiritual heart is also the essence of the human nafs which can function as a guide, controller, controller of the structure of other nafs. If this heart functions normally, then human life will be good and in accordance with its original nature, because this heart has a divine nature or rabbaniyyah.

Al-Ghazali argues that the heart has an instinct called al-nur al-ilahy (the light of God) and al-bashirah al-bathinah (inner eye) which radiates faith and belief. The heart psychologically has emotional powers (al-infi'aliy) which can cause a sense of power (al-syu'ur) (Arif, 2015: 157-158).

\section{Dimension of Intellect (Al-'Aql)}

Intellect is the nafsani substance that is located in the brain and functions to think. Intellect is the result of brain work. Intellect also has a light of conscience prepared to be able to acquire knowledge and cognition. Intellect is the power of human thought to acquire knowledge that is rational and can determine human existence. Intellect is able to gain knowledge through argumentative power 
and also shows the substance of thinking, thinking, understanding, describing, memorizing, finding and saying something. For this reason, the nature of reason is humanity (insaniyah), so it is also called fithrah insaniyah. Psychologically reason has the function of cognition (creativity). Reason is not heart. It is a separate dimension in the aspect of nafs which is located in the brain which functions to think. Intellect has similarities with the heart in gaining cognition power, but the method and results are different. Intellect is able to achieve rational knowledge but unable to reach suprarational knowledge. Intellect is able to uncover abstract things but has not been able to feel its nature. Intellect is able to deliver human existence at the level of consciousness but is unable to deliver at the level of supra-consciousness. According to al-Ghazali, reason has many activities; al-Nadlar (watching with attention), al-Tadabbur (paying close attention), al-Ta'ammul (pondering), alIstibshar (seeing with inner eyes), al-I'tibar (interpreting), al-Tafkîr (contemplating) thinking) and al-Tadzakkur (remembering) (Muhammad Ali,2016:,47).

\section{Dimensions of Lust (An-Nafs)}

According to Imam al-Ghazali, in human beings there are three potential passions. (1) Lust Hayawaniyyah, namely a tendency to animal behavior. This lust is identical to the behavior of livestock animals in terms of looking for physical satisfaction or satisfaction, such as covetousness, no shame and so on. (2) Lust Sabu'iyyah, namely lust that drives the behavior of wild animals. Examples are someone who likes to oppress others, likes to eat the rights of others, likes to attack others, and all behaviors that are filled with hatred, enmity, envy, anger and mutual fist which invites people to the path of error. This passion drives human beings to justify all the evil they do. (4) Lust rabbaniyah, namely the lust for power that comes from the spark of Divine light. This passion lies in human reason. By using this power, humans can subdue the three forces above. By using common sense, humans will be able to sort out which actions are in line with God's commands and which actions deviate from God's provisions. Intellect will guide you to take a spiritual journey to Allah SWT (Zainal Arifin, $2016: 345$ ).

The three components of the above nafsani, namely the dimensions of the heart, mind and nafs are integrated to realize a human behavior or behavior. This is due to the fact that the three interact with one another and cannot be separated. 
It's just that one of them is sometimes more dominant over other components.

From the explanation above it can be understood that the relationship of motivation and human behavior in the perspective of Islamic psychology emphasizes religious motives (spiritual), both in psychological and physiological conditions of humans. The religious motives which then encourage people to behave in line with Islamic religious norms.

\section{Implications of Causality in Human Motivation and Behavior Towards the Peak of Sufistic Experience}

The aspect of spiritual preservation in the process of forming spirituality is one of the most urgent aspects. This is due to the aspect of spiritual preservation can be said as a fundamental foundation in the creation of spiritual conditions In a mystical perspective, the process of forming spiritual spirituality to achieve perfect human degrees (insan kamil), namely the actualization of the dimensions of divine values (uluhiyah) in a person (Islamy, 2018: 242).

The issue of the peak human spiritual experience is not only a monopoly of Sufism discipline that has been developing for so long. But it is a phenomenon that makes other disciplines interested in studying it. One discipline, which is methodologically based on science, is interested in disclosing it is the discipline of psychology. One of the most important figures is William James. He has consistently tried to show that the problem of spiritual experience is an issue worth exploring based on scientific principles as generally held by adherents of this science. Meanwhile, in the Islamic tradition, the issue of spiritual experience with God is much studied in the Sufism tradition. one of his famous figures was alGhazali. The presence of al-Ghazali has succeeded in mediating the apparent opposition between orthodoxy supporters, who prioritize the exoteric aspects of religion with heterodoxists who prefer the esoteric dimension of religion. The issue of spiritual experience with God which is thicker nuanced isoteric, successfully bridged al-Ghazali so well, that the ideas of Sufism can again be accepted by adherents of Islamic orthodoxy (Komarudin, 2012: 485).

The path taken by a Sufi to reach a high level of spiritual peak experience can see his God with the eyes of his heart and finally unite with Him very long and full of challenges. Therefore only very few people can get to the top of the destination of Sufism. This road is called tariqah 
which literally means road or method. In Sufi literature, no one gives the same number about the number of maqamat and ahwal that must be passed by a Sufi. These differences are caused because the peak of Sufism is not reached by learning or based on theory, but he is based on experience or charity of a salik. Thus the outlook and spiritual experience of a Sufi is different from other Sufis in undergoing stages to reach the peak of Sufism. However, almost all of them agreed to use some special pronunciations such as: zuhd, taubah, sabr, tawakkal, and al-rida which were steps to reach the peak of Sufism, namely closeness to Allah SWT. as close as possible until between him and God is not limited or revealed to all secrets. This goal is mostly Sufi terminology with ma'rifat al-haq, that is when a servant has been disconnected from the material (physical) (Muh Ilham, 2017:173-174). From this it can be understood that the process of traveling to the spiritual peak experience experienced by a Sufi through various steps (processes) which is closely related to the motivation of a Sufi in carrying out various steps in the form of behavior or deeds praised before reaching the spiritual peak conditions that will be experienced.
In addition to the various steps experienced by each Sufi in reaching the ultimate spiritual experience, some of them have also formulated their respective manhaj (methods), as follows.

Al-Gazaliy is a Sufi who expresses the achievements of his spiritual experience with the term ma'rifah. This, of course departs from his experience before plunging into the world of Sufism, he was much involved in philosophy which ends him to the level of doubt about the science of philosophy. To get out of this doubt, alGazali said that he came out with the light emitted by God in heart, and this light is the key to most knowledge. And knowledge like this in Sufi terms is known as 'ilm ladunni. To achieve or obtain this knowledge, according to al-Gazaliy, he must go through a number of conditions as follows. First, one must obtain various ma'rifahs based on theorems of logic. Second, must have good intentions, honest and truly in undergoing riyadah, love the goals to be achieved and be aware of all things that damage him and that can turn him away from his goals. Third, he must reflect a lot on what he has gained by continuing to carry out riyadah, and when his heart is open and ready to receive the Divine Nurses' rays. (Muh Ilham, 2017:195). 
al-Sarraj states that mahabbah has three levels. First, ordinary love, which is always remembering God with remembrance, always chanting the names of God and having pleasure in dialogue with God. Second, the love of a siddik is someone who knows God in his greatness in his power, in his knowledge, love like this can remove the veil that separates a person from God so that he can see the secrets to God. Third, the love of Arif people, those who know God well. Love like this arises because you already know the Lord well, so that what you see and feel is no longer love, but your loved one, so that the qualities of the loved one come into the person who loves (Tasmin Tangngaren, 2017: 89-90).

The Sufi Mayshur with the peak of the achievements of the next Mahabbah is the Rabi'ah al-Adawiyah. The condition of his love for God that was more intimate and unconditionally caused him to receive the light of God which was implemented in the ma'rifah in the form of God's grace to Sufis who truly and truly loved God, so God revealed the veil from the Sufi view and with the opening of the veil. To achieve this, we must go through lower forms. In general, mahabbah is divided into three levels. First, mahabbah ordinary people, who always remember God.
Second, the mahabbah of the shiddiq, that is the mahabbah that is able to open the veil between man and God, removes the qualities of self and heart full of longing for Him. Third, mahabbah wise people. that is, the Mahabbah who knows right to God, who is no longer considered love, but the beloved Self (Ach. Maimun, 2004: 178-181).

A well-known Sufi in the history of Sufism with the achievements of Marifah beside Rabi'ah al-Adawiyah is Zunnun al-Mishry. According to Zunnun, he obtained wisdom because of God's generosity. If God did not open the veil from the eyes of his heart, he would not be able to see God. As mentioned in Sufism literature, Sufis strive to draw closer to the bottom and God sends His grace from above. In other words, wisdom comes when Sufi love from below is answered by God from above. More about this marifah station, in Sufism literature it is said that. First, if the eyes contained in human hearts are open, the eyes will be closed and when that is seen only God. Second, ma'if is a mirror. If the Sufi looked in the mirror, all he would see was God. Third, what the Sufi sees, both at bedtime and when he wakes up is only God. Fourth, if ma'ififah takes the form of matter, the light which he shines is dark, all who see 
it will die because they cannot see its brightness and beauty. But the Sufi who can capture the light of the ma'if with his eyes, will be filled with his heart with a deep love for God. It is not surprising that the Sufi feels dissatisfied with ma'ififah, but he wants to be closer to God, which is implemented in the ittihad station, which is experiencing union with God (Tasmin Tangngaren, 2017: 91).

Furthermore, the Sufi who was famous in achieving ittihad, was Abu Yazid al-Bustami. When the Sufi arrives at the threshold of ittihad which is the final culmination of the Sufi journey, it is usually strange phrases which in Sufi terms are called syatahat. Like al-Bustami in ittihad speaking in the name of God. Or rather "God speaks" through al-Bustami's tongue. After the dawn prayer, in the remembrance of al-Bustami he said: There is no god but Me, then worship Me "and further he said the Most Holy I, Most Holy I, Most Great I". People who heard him thought he was crazy and they left him.

The oneness of God with Sufis in Sufism literature is not only referred to as ittihad, but other terms are also called hulul as introduced and experienced by alHallaj. According to al-Hallaj, before arriving at this hulul condition first a Sufi must experience mortal and baqa, ie the destruction of the soul or the destruction of feelings and awareness of the existence of a gross body in the self. Like ittihad, hulul also occurs through mortal and baqa. But the context of al-fana al-Hallaj is different from al-fana for al-Bustami. For al-Bustami, in a mortal state he was completely destroyed and what was in him was only God. As for al-Hallaj, the self remains, what happens is the unity of the divine nature within him. According to alHallaj, God seems to have two basic qualities, namely divinity (Lahut) and humanity (Nasut). Conversely, humans also have a divine nature within themselves. It is this nature and human nature that causes God and humans to be able to work. Al-Hallaj's experience in hulul is that he said "I am the right one" is not al-Hallaj's spirit saying that word, but God's spirit taking place in him (Muhammad Zamrud Tualeka, M. Wahid Tualeka, 2017:4).

Following on from the understanding of hulul is wahdat al-wujud as introduced and experienced by Ibn Arabiy. According to him, the nasut in hulul was changed by Ibn Arabiy to become khalq "creature" and lahut to haq "God". Khlaq and Haq are two aspects of each thing. The outer aspect is called khalq and the inner aspect is called haq. 
Ibn Arabiy gave an understanding that God explained in hulul wanted to see himself outside of himself and therefore made him the nature. Then this nature is a mirror for God. When he wants to see himself, he looks at nature. In things that exist in nature, because in each of those objects there is a divine nature, God sees Himself. From here arises the understanding of unity. There is a lot in nature, but actually it's one. He could not help this as someone who saw himself in a number of mirrors placed around him. In each mirror he saw himself. In the mirror he looks a lot, but he is actually one. In connection with this, one thing must be known that the Sufis actually never claimed to be God. This can be seen from the Sufi words (al-Hallaj) "I am the secret of the Truly Righteousness, and not the Truthfulness that is me, I am only one of the true things, so distinguish between us." (Khamid, 2014:107).

With an explanation of the various spiritual peak experiences experienced by some of the Sufi shops above, it can be understood that the peak of the spiritual journey, namely towards being together with God even united with Him (ittihad) must pass through various stages and varying spiritual conditions. The various stages and spiritual conditions are closely related to the motivation of a Sufi in carrying out various practices or behaviors in achieving the spiritual peak experience that he will experience

\section{CONCLUSION}

The relationship of motivation and human behavior in the perspective of Islamic psychology that is more likely to emphasize religious motives (spiritual), both in psychological and physiological conditions of humans. The religious motives which then encourage people to behave in line with the teachings of Islam.

As for the spiritual peak experience, motivation and behavior in Islam is very closely related to the process towards the peak spiritual experience of humans. Such is the case as experienced by Sufis. The various stages and spiritual conditions experienced by various Sufi figures in the process of reaching the spiritual peak are very diverse and subjective according to the psychological character and personal condition of each. The level of quality of comprehension and practice in such a diverse process can be used as a method for Muslims in the framework of spiritual experience. 


\section{REFRENCES}

Ali, M. (2016). Hakekat Kepribadian dalam Psikologi Islam. Tarbawiyah, 13 (1).

Arif, S. (2015). Manusia dan Agama. Islamuna, 2 (2).

Arifin, Zainal, "Psikologi dan Kepribadian Manusia dalam Perspektif alQur'an," Hikmah, Vol. XII, No.2(2016).

Gumiandri, S. (2011). Kepribadian Manusia dalam Perspektif Psikologi Islam (telaah Kritis Atas Psikologi Kepribadian Modern). Holistik, 12 (1).

Ilham, M. (2017). Puncak Klimaks Capaian Sufistik Dalam Perspektif Tasawuf. Rausyan Fikr, 13 (2).

Istiani, N., \& Islamy, A. (2018). Objektifikasi Nilai-nilai PsikoSufistik dalam Pendidikan Spiritual. Hikmatuna: Journal for Integrative Islamic Studies, 4 (2).

Jamaa, L. (2011). Dimensi Ilahi dan Dimensi Insani dalam Maqasid al-Syari'ah. Asy-Syir'ah, 45 (2).

Khamid. (2014). Wahdat Al Wujud Dan Insan Kamil Menurut Ibnu Al Arabi (Kajian Tasawuf Modern). Jurnal Studi al-Qur'an, 10 (10).

Komarudin. (2012). Pengalaman Bersua Tuhan: Prespektif William James dan al-Ghazali. Walisongo, 20 (2).

Maimun, A. (2004). Mahabbah Dalam Tasawuf Rabi'ah Al-Adawiyah : Apresiasi atas Rintisan Mistik Sejati dalam Islam. Millah, 3 (2).

Maryani. (2016). Motivasi dalam Perspektif Islam. An-Nahdhah, 10 (2).

Maslow, H., \& Abraham. (1987). Motivation and Personality, New York: Longman.
Nurlita, S. (2015). Psikologi Islam Kontemporer. Jurnal Studi AlQur'an, 11 (1).

Nurwatie, A., Fauzia, R., \& Akbar, S. N. (2012). Perspective Of Abraham Maslow's Humanistic Psychology In Reviewing Motive of Murder. Jurnal Unpad,.1 (1).

Tangngaren, T. (2017). Puncak-Puncak Capaian Sufistik Dalam Perspektif Metodologis. Jurnal Aqidah-Ta, 3 (1).

Yuriadi. (2016). Prilaku Manusia dalam Perspektif Islam. El-Furqania, 3, (2).

Zamrud, M. T., \&, Tualeka, M. W. (2017). Kajian Kritis Tentang Tasawuf Al Hallaj. Al-Hikmah: Jurnal Studi Agama-Agama,.3 (2). 